British and Mercantile Insurance Company to appoint him to become Manager of the Company in Edinburgh. This important post he held only for some six years, as unfortunately his health had become impaired and necessitated retirement.

On his resignation he went to live at Melrose on Tweedside, where for over twenty years he led a pleasant, health-restored life, contentedly retired from the arena of official life, where he had in his day played such a distinguished part.

His last illness was very short and his friends were surprised to hear that he had passed over on the 28th December 1934.

W. L.

\title{
LOUIS ERNEST CLINTON
}

CLINTON entered the service of the Sun Life Office in I9oz and became an Associate of the Institute in 1904. His work as a student attracted the attention of his Tutor, and in 1906 he was offered and accepted a position in the Life Department of the Alliance. There he found himself associated with a group of young actuarial students who already showed promise of the distinction they were afterwards to attain in the profession, and amongst them he formed lasting friendships.

Some of them were senior to him, and after he had become a Fellow of the Institute in r9ro he came to the conclusion that his prospects of advancement in the Alliance were not sufficient to satisfy his ambition. Accordingly in December I9ro he applied for and obtained a position on the actuarial staff of the Provident Association of London, Ltd., whose Actuary at that time was the late Ralph Price Hardy. On Hardy's death in 1913 Clinton was appointed Actuary, and retained that position up to the time of his death.

At the time of his appointment Clinton had stipulated that he should be permitted to develop a private practice, and he immediately set about getting the necessary experience of Friendly Society and Pension Fund work by assisting Hardy, Manly, Ackland and King in their work. In I9I2 his name appeared with those of Manly and Ackland as contributor to a paper on "The Superannuation and Pension Funds of certain Metropolitan Borough Councils." With growing experience he soon gained a reputation as a sound Consultant, and, when the leaders in consulting work died, Clinton's practice rapidly increased.

He served on the Council of the Institute from 1919 to 1928 and on the Board of Examiners from 1920 to 1923 . In discussions at the Institute he took little part, but on the rare occasions when he spoke his contribution was always worth hearing.

The growing demands of his large practice seemed to make him lose touch during recent years with Institute affairs, and there is little doubt that for some years before his death he had been overworking. His 
friends often urged him to take a partner, but he refused to consider the suggestion on the plea that his young son, still at school, would come into the practice in due course, and that he could carry on alone until the boy was qualified to assist him.

Two years ago Clinton met with a motor accident, and those who have been most closely associated with him date the beginning of his last illness from this accident. A year ago he had a breakdown, but after a time was able to resume his work. Unfortunately there was soon a recurrence, and at the time of his death (on the 3 rd February) through an accident, he was still away from business, though he had so far progressed that, with the consent of his medical adviser, it had been definitely arranged that he should, in the following week, gradually resume his work for the Provident Association, to which he was looking forward with much satisfaction. His untimely death, however, prevented this.

Clinton was a man who set before himself the highest standard of professional conduct, and rigidly adhered to that standard. He was a good speaker with an attractive presence, and was as much at home in discussing financial problems with a Board of Directors as in addressing the members of a Friendly Society or Pension Fund and explaining to them in simple language the problems with which their Committee had to deal.

Through his death at the early age of 48 the Institute has lost an able and distinguished member, and his many friends have lost a "good companion."

H. E. M.

\section{V. L. CHARLIER}

WE record, with much regret, the death of Dr Charlier, the well-known Scandinavian physicist, astronomer and statistician. It would be inappropriate to discuss the work that probably meant most to him, but his name is familiar to actuaries and statisticians all the world over for his work on the law of error and frequency functions. Thirty years ago Charlier published in Arkiv för Matematik a paper, "Ueber das Fehlergesetz," and followed it up a year later with his well-known " Researches into the Theory of Probability" which appeared in Meddelanden frain Lunds Astronomiska Observatorium. Charlier gave two series for expressing frequency distributions; one, which he called Type A, was formed from the normal curve and its differential coefficients and was applied to bell-shaped curves with little skewness; the other, Type B, was formed from the Poisson approximation and its differences and was applied to distributions showing considerable skewness. He showed that, with the help of these two series, a very wide range of statistical examples could be satisfactorily graduated with the help of moments, 